\title{
PENGEMBANGAN SISTEM STUDENT RELATIONSHIP MANAGEMENT (SRM) DAN PENERAPANNYA PADA PERGURUAN TINGGI DI INDONESIA (Studi Kasus MTI UGM Yogyakarta)
}

\author{
Yonathan Dri Handarkho
}

\begin{abstract}
Currently, application of Information Technology in higher education in Indonesia is more directed and focused on administrative and management areas only. This was resulted in no system which aims to monitor in detail the process of student's academic activities in the class available.

On the other hand, through a process of observation against student's academic activities, college can obtain knowledge that can be used to support and work up in improving the performance of student's academic activities .

Based on these issues, there is a concept called the SRM. SRM (Student Relationship Management) system was inspired by the CRM (Customer Relationship Management), which handles and manages the relationship between colleges and students to gain knowledge that are useful to both parties, especially for students. Furthermore this knowledge can be used to support and improvimg students' academic performance.

SRM applications which were developed in this study based upon the technological infrastructure that traditionally supports the Business Intelligence. The datas that used in this research came from datas of MTI UGM student's academic activities. This datas will be stored in a dimensional database which will be analyzed by using fuzzy classification method for identifying patterns of academic activities that occurred. The result of process analysis will be used by college to determine the appropriate action for students and to improve the performance of academic activities of the students'.
\end{abstract}

Key words: academic activities, knowledge, performance, SRM, Business Intelligence, fuzzy classification.

\section{Pendahuluan}

\subsection{Latar Belakang}

Pemanfaatan teknologi informasi di dalam lingkungan perguruan tinggi di Indonesia saat ini, lebih terkonsentrasi pada area administratif. Hal tersebut berdampak pada ketiadaan sebuah sistem khusus yang berfungsi memantau proses aktivitas akademik mahasiswa di kelas secara periodik.

Padahal dari proses observasi terhadap aktivitas akademik mahasiswa, dapat diperoleh suatu pengetahuan yang berguna bagi kepentingan mahasiswa. Pengetahuan tersebut nantinya dapat digunakan oleh pihak pengelola perguruan tinggi untuk mendukung dan membantu performa akademik dari mahasiswa yang bersangkutan. Dari isu tersebut maka muncullah sebuah konsep yang bernama Student Relationship Management atau disingkat SRM. SRM adalah sebuah sistem yang menangani dan mengelola relasi antara perguruan tinggi dengan mahasiswanya untuk mendapatkan suatu pengetahuan yang berguna dalam meningkatkan performa aktivitas akademik dari mahasiswa.

\subsubsection{Perumusan Masalah}

"Bagaimanakah membangun dan menerapkan sebuah sistem berbasis Student Relationship Management (SRM) pada sebuah institusi perguruan tinggi (studi kasus MTI UGM) sehingga dapat mendukung performa akademik dari mahasiswa serta meningkatkan relasi antara institusi pendidikan dengan mahasiswanya? ”

\subsection{Tujuan Penelitian}

Penelitian ini bertujuan untuk mengimplementasikan sebuah konsep Student Relationship Management (SRM) di sebuah perguruan tinggi di Indonesia (studi kasus di MTI UGM Yogyakarta), dengan harapan dapat membantu pihak perguruan tinggi dalam melakukan observasi terhadap performa aktivitas akademik mahasiswa. Tujuan akhir dari proses observasi tersebut adalah agar relasi antara mahasiswa dengan institusi dapat berjalan dengan baik sehingga berdampak positif pada performa dari aktivitas akademik mahasiswa.

\subsection{Keaslian Penelitian}

Penelitian ini adalah pengembangan dari penelitian sebelumnya yang dilakukan oleh Maria Beatriz Piedade dan Maribel Yasmina Santos (2008) didalam sebuah jurnal yang berjudul "Student Relationship Management : Concept, Practice and Technological Support ". Penelitian tersebut sebatas memaparkan konsep SRM secara umum 
dan berbagai macam teknologi informasi berbasis business intelligence yang mendukungnya dan tidak mencakup implementasi dan penerapan disebuah institusi secara nyata dan detil. Berbeda dengan penelitian tersebut, penelitian ini mengarah pada penerapan dan implementasi dari konsep yang telah ditawarkan oleh penelitian sebelumnya yaitu membangun aplikasi SRM dan menerapkannya di sebuah perguruan tinggi di Indonesia dengan mengambil studi kasus data dari MTI UGM Yogyakarta.

\section{Tinjauan Pustaka dan Landasan Teori 2.1 Tinjauan Pustaka}

Terdapat beberapa penelitian yang memiliki keterkaitan dengan konsep Student Relationship Management (SRM) di institusi pendidikan. Seeman dan O'Hara (2006) di dalam jurnalnya yang berjudul Customer Relationship Management in Higher Education memaparkan penerapan CRM di perguruan tinggi yang bertujuan meningkatkan kepuasan terhadap program dan layanan pendidikan yang disediakan oleh di perguruan tinggi tersebut. Hasil akhir dari penelitian tersebut adalah memaparkan keuntungan dari penggunaan CRM pada berbagai kebijakan di institusi pendidikan termasuk di dalamnya student-centric focus, meningkatkan data konsumen dan manajemen prosesnya, dengan tujuan akhir untuk meningkatkan loyalitas, retensi, dan kepuasan mahasiswa terhadap program dan layanan dari sebuah institusi perguruan tinggi.

Machado, dkk (2007) pada jurnalnya yang berjudul Customer Relationship Management in Universities and Research Centres memaparkan penelitian dan pandangan yang juga cukup mendekati konsep SRM. Jurnal tersebut menjelaskan skenario penerapan Customer Relationship Management (CRM) pada universitas dan lembaga pendidikan atau penelitian berdasarkan kondisi akademik yang berjalan di negara Brasil. Berbeda dengan konsep SRM yang lebih terfokus kepada relasi dengan mahasiswa, pada penelitian tersebut, ruang lingkup relasi CRM diperluas kepada pihak alumni, dosen, dan institusi yang menjalin kerja sama dengan universitas baik dari sisi bisnis ataupun akademik. Di dalam penelitian tersebut, Machado, dkk (2007) mencoba memanfaatkan tools CRM komersial yang beredar di pasaran (PeopleSoft, Siebel, dan SAP CRM) namun pada akhirnya tidak semua kebutuhan yang diperlukan dapat terpenuhi sehingga pengembangan sistem secara mandiri menjadi perlu untuk dilakukan.

Dalam jurnalnya yang berjudul Student Relationship Management: Concept, Practice and Technological Support, Piedade dan Santos (2008) menawarkan sebuah konsep SRM dengan lebih spesifik mulai dari konsep awal, strategi penerapan, dan penggunaan teknologi informasi yang sesuai. Di dalam penelitian tersebut, SRM dipandang sebagai sebuah sistem yang secara tradisional mendukung Business Intelligence yang nantinya akan digunakan sebagai tools untuk memperoleh suatu knowledge dari aktivitas akademik mahasiswa. Akan tetapi pemaparan dan hasil akhir yang disampaikan di dalam jurnal tersebut masih sebatas konsep SRM secara umum baik dari sisi teknologi dan belum menyentuh pada tahap implementasi pada sebuah perguruan tinggi secara mendetail.

Berbeda dengan penelitian yang dijabarkan di atas, penelitian kali ini lebih ditujukan dan diarahkan pada penerapan dan implementasi dari konsep SRM yang ditawarkan oleh Piedade dan Santos (2008) pada penelitian sebelumnya. Penelitian ini diarahkan pada proses pembangun aplikasi SRM dan menerapkannya di sebuah perguruan tinggi di Indonesia dengan mengambil studi kasus di MTI UGM Yogyakarta. Metode Business Intelligence yang digunakan pada penelitian ini untuk memperoleh suatu knowledge dari data aktivitas akademik mahasiswa adalah klasifikasi berbasis logika fuzzy atau disebut fuzzy classification.

Metode fuzzy classification juga diterapkan oleh Meier, dkk (2005) pada jurnalnya yang berjudul Using a Fuzzy Classification Query Language for Customer Relationship Management. Pada penelitian tersebut, Meier,dkk (2005) menggunakan fuzzy classification sebagai 'alat' untuk memperoleh knowledge dari konsumen pada skenario toko online dengan tujuan akhir memaksimalkan nilai riil dari konsumen.

\subsection{Landasaan Teori}

\subsubsection{Konsep Dasar SRM}

SRM dijabarkan sebagai sistem yang ditujukan untuk mengelola relasi antara pihak institusi dengan mahasiswan. SRM menggunakan data aktivitas akademik dari mahasiswa untuk kemudian dilakukan suatu analisis terhadap data tersebut menggunakan sebuah metode yang didasarkan pada pemanfaatan teknologi informasi. Dari proses analisis tersebut akan didapatkan suatu knowledge yang akan dipergunakan dalam proses pengambilan suatu tindakan terhadap mahasiswa, dengan tujuan akhir membantu meningkatkan performa akademik dari mahasiswa tersebut (Piedade, 2008). 


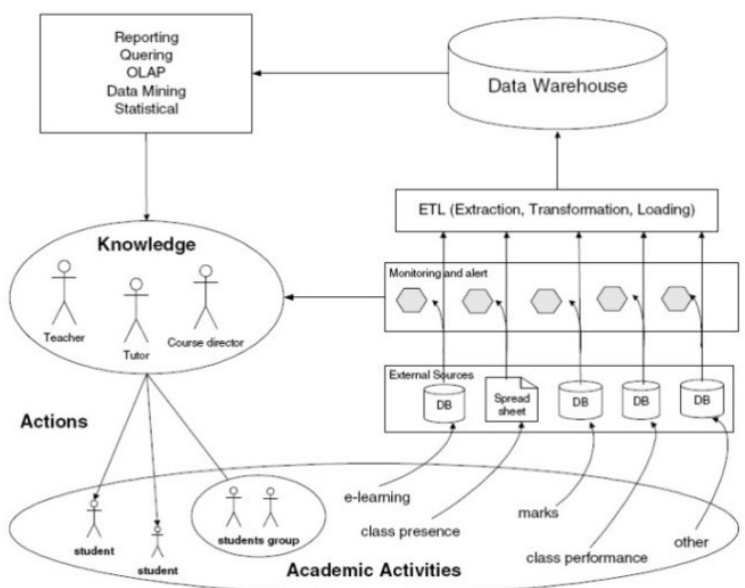

Gambar 2.1. gambaran umum sistem SRM (Piedade, 2008)

\subsubsection{Arsitektur SRM}

Arsitektur dari SRM dipahami sebagai sebuah sistem yang didasarkan pada teknologi infrastruktur yang secara tradisional mendukung Business Intelligence yang nantinya akan digunakan sebagai tools untuk memperoleh suatu knowledge dari aktivitas akademik mahasiswa (Piedade, 2008). Arsitektur dari sistem SRM terdiri komponen data acquisition and storage, data analysis, interaction, dan assesment (Piedade, 2008).

Penjelasan dari keempat komponen tersebut adalah sebagai berikut:

- Komponen data acquisition and storage bertanggung jawab terhadap proses penyimpanan data mahasiswa di dalam basis data.
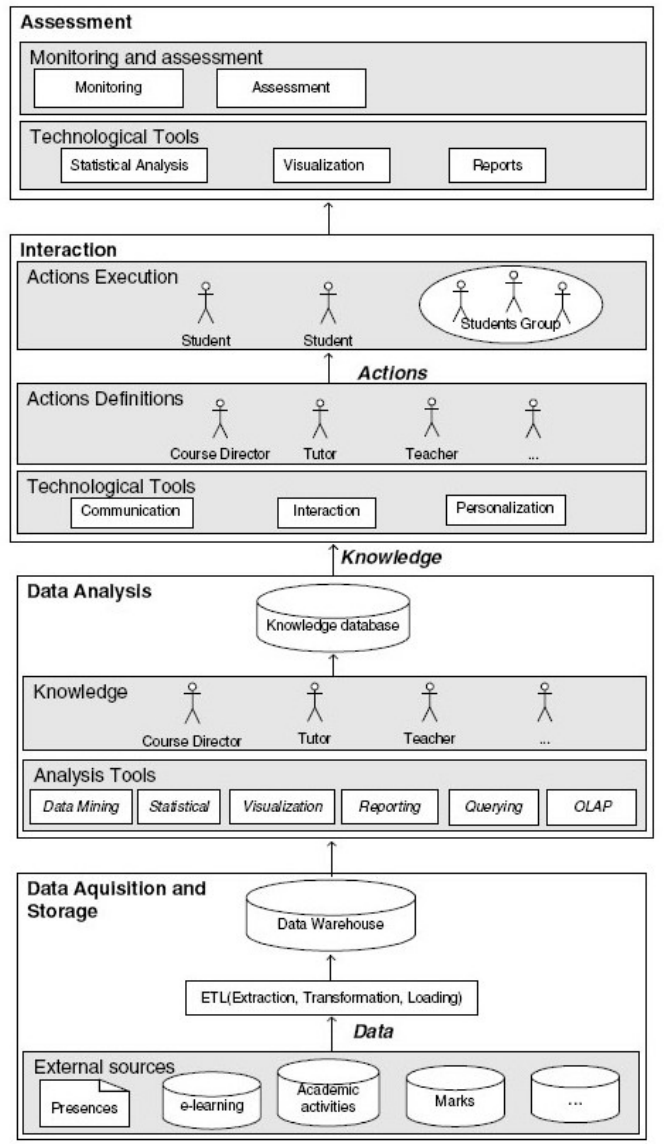

오 student

Gambar 2.2. Arsitektur sistem SRM (Piedade, 2008) 
- Komponen data analysis bertanggung jawab terhadap proses pemerolehan knowledge dengan menganalisis data menggunakan metode analisis yang mampu mengidentifikasi sebuah pola dan perilaku data.

- Komponen interaction bertanggung jawab untuk memelihara hubungan antara institusi dengan mahasiswa. Hal tersebut diwujudkan melalui proses perolehan pengetahuan dari aktifitas akdemik mahasiswa.

- Komponen Assessment bertanggung jawab terhadap penilaian terhadap semua tindakan yang telah dieksekusi dan dampak yang dihasilkan dari tindakan tersebut.

\subsubsection{Fuzzy Classification}

Fuzzy classification adalah salah satu metode dari data mining yang dapat dipergunakan untuk memperoleh sebuah pengetahuan dari sejumlah data. Fuzzy classification didapatkan dengan memperluas sebuah atribut dengan sebuah context model. Untuk mengubah kebentuk klasifikasi, model relasional diperluas oleh contex model dengan tujuan memperoleh ruang lebih untuk sebuah klasifikasi berbasis fuzzy. Gambar 2.3 menunjukkan bagaimana sebuah atribut diperluas menggunakan context model.

Meier (2005) mengambil sebuah contoh sederhana dari sebuah hubungan manajemen antara institusi keuangan dengan konsumennya. Untuk mempermudah, konsumen akan dievaluasi berdasarkan atribut turnover (perputaran modal) dan payment behavior (perilaku pembayaran) dengan penjabaran sebagai berikut:

- Turnover direpresentasikan dalam dolar. Atribut domain didefinisikan oleh [0 .. 1000] dan dibagi ke dalam kelas-kelas equivalence [0 .. 499] untuk low turnover dan [500 .. 1000] untuk high turnover.

- Payment Behavior : Terdiri dari empat domain yaitu domain \{in advance, on time, behind time, too late\} dengan kelas equivalence $\{$ in advance, on time \} untuk attractive payment behavior dan \{behind time, too late \} untuk non attractive payment behavior.

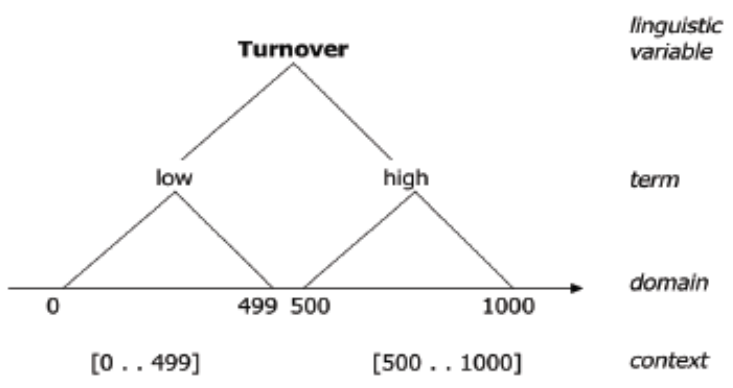

Gambar 2.3 konsep variabel linguistik (Meier, 2005)

Dari kedua atribut yang telah didefinisikan di atas, maka akan terbentuk empat buah kelas yaitu kelas C1, C2, C3, dan C4 seperti ditunjukkan pada Gambar 2.4.

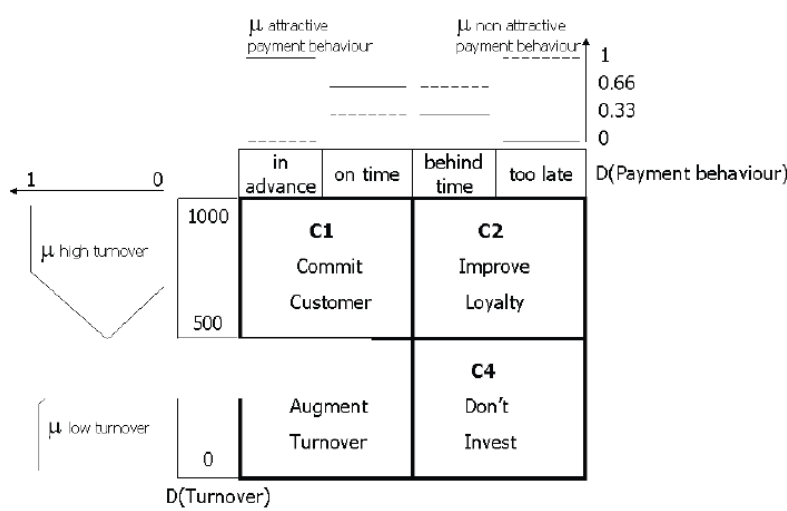

Gambar 2.4 Fuzzy classification space yang didefinisikan oleh turnover dan payment behavior (Meier, 2005)

Keempat kelas yang terbentuk dari $\mathrm{C} 1$ sampai dengan $\mathrm{C} 4$ didefinisikan sebagai 'Commit Customer' (C1), 'Improve Loyalty' (C2), 'Augment Turnover' (C3), and 'Don't Invest' (C4) (Meier, 2005). Dengan context model tersebut, dan penggunaan variabel linguistik, serta fungsi keanggotaan, ruang klasifikasi telah berubah menjadi fuzzy. Perbedaan yang sangat nyata antara fuzzy classification dengan sharp classification adalah pada fuzzy classification, konsumen dapat dikelompokkan pada lebih dari satu kelas pada waktu yang bersamaan (Meier, 2005). 


\subsubsection{Implementasi Sistem SRM}

Gambar 2.5 menunjukkan gambaran umum dari sistem yang dikembangkan pada penelitian ini. Data aktivitas akademik mahasiswa akan disimpan di data marts untuk selanjutnya diolah menggunakan fuzzy classification untuk diperoleh sebuah pengetahuan yang akan digunakan sebagai dasar untuk melakukan tindakan terhadap mahasiswa atau grup mahasiswa yang bersangkutan. Penyampaian tindakan dapat melalu pihak perantara seperti dosen wali atau pengawas.

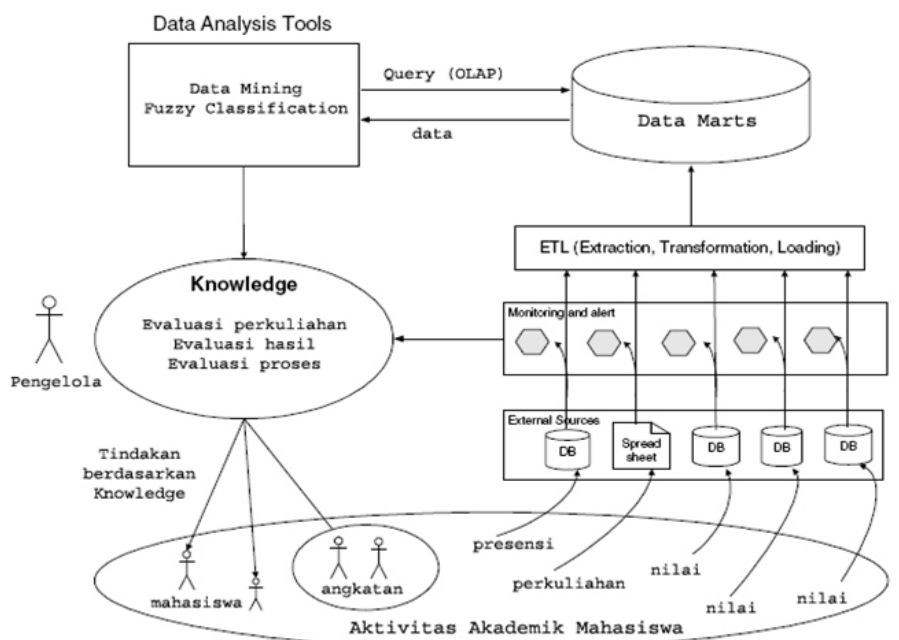

Gambar 2.5 Gambaran umum implementasi model SRM berdasarkan model Piedade

\section{Metode penelitian}

\subsection{Bahan penelitian}

Bahan yang digunakan didalam penelitian ini adalah sebagai berikut:

1. Data aktivitas akademik mahasiswa kelas reguler di MTI UGM Yogyakarta yang terdiri dari data presensi dan data nilai. Data nilai terdiri dari nilai akhir dan nilai komponen penyusun nilai akhir dari setiap mata kuliah.

2. Bahan yang kedua adalah data akademik MTI UGM Yogyakarta meliputi data kurikulum, data jadwal perkuliah, data dosen, data catatan aktivitas kemajuan kelas dan data identitas mahasiswa.

3. Bahan yang ketiga adalah proses bisnis dan entitas yang berhubungan dengan pengelolaan data akademik mahasiswa di MTI UGM Yogyakarta.

\subsection{Alat Penelitian}

Peralatan yang diperlukan didalam penelitian ini adalah seperangkat komputer dengan spesifikasi yang cukup untuk menjalankan perangkat lunak visual studio.Net 2008 dan Microsoft SQL Server 2008 di atas sistem operasi berbasis windows $x p$ atau windows vista.

\subsection{Analisis Dan Perancangan Perangkat Lunak}

Sistem SRM yang dikembangkan di dalam penelitian ini terdiri dari dua buah fungsionalitas yang saling terkait dan terintegrasi. Yang pertama adalah pencatatan data yang terkait dengan aktivitas akademik mahasiswa menggunakan basis data operasional. Yang kedua adalah proses analisis terhadap data aktivitas akademik yang disimpan pada data marts untuk selanjutnya diperoleh sebuah pengetahuan yang dibutuhkan oleh pihak perguruan tinggi.

\subsubsection{Pemerolehan Pengetahuan}

Dalam relasi antara institusi pendidikan dengan mahasiswa, metode fuzzy classification dapat digunakan untuk mengklasifikasi secara lebih detil, seperti mahasiswa rajin, kurang rajin, atau mahasiswa manakah yang membutuhkan bimbingan atau tidak membutuhkan bimbingan. Dalam bentuk permasalahan yang lain, fuzzy classification juga dapat membantu mengkelompokkan jadwal perkuliahan manakah yang berjalan dengan efektif, mendapat respon baik ataupub respon kurang baik mahasiswa.

Dimisalkan sebuah institusi hendak mengevaluasi program beasiswa untuk periode selanjutnya. Kelayakan mahasiswa penerima beasiswa akan dievaluasi berdasarkan variabel indeks prestasi dan frekuensi kehadiran selama perkuliahan. Kedua atribut tersebut dijabarkan sebagai berikut: 
- Indeks prestasi didefinisikan dalam [0.0 ... 4.0] dan dibagi kedalam dua buah kelas equivalence yaitu [3.0 .. 4.0] untuk 'IP baik' dan [0.0 .. 2.99] untuk 'IP kurang'. Selanjutnya konten dari kelas equivalence diperluas menjadi $[2.8$.. 4.0] untuk 'IP baik' dan [0.0 .. 3.15] untuk 'IP kurang'.

- Frekuensi kehadiran dinyatakan dalam [0 ... 100] dan dibagi kedalam dua buah kelas equivalence yaitu [75 .. 100] untuk 'kehadiran baik' dan [0 .. 74] untuk 'kehadiran kurang'. Setelah diperluas maka 'kehadiran baik' adalah tetap [75 .. 100]. Sedangkan 'kehadiran kurang' menjadi [0 .. 80].

Diketahui indeks prestasi (IPK) dan frekuensi kehadiran dari empat mahasiswa yang akan dievaluasi adalah sebagai berikut:

\begin{tabular}{|l|l|l|}
\hline Mahasiswa & \multicolumn{1}{|c|}{$\begin{array}{c}\text { Indeks } \\
\text { Prestasi }\end{array}$} & Kehadiran \\
\hline Andi & 3,8 & 90 \\
\hline Budi & 3,10 & 70 \\
\hline Caca & 2,95 & 60 \\
\hline Dani & 2,40 & 70 \\
\hline
\end{tabular}

Gambar 3.1 menggambarkan pemodelan dari fuzzy classification untuk evaluasi beasiswa mahasiswa.

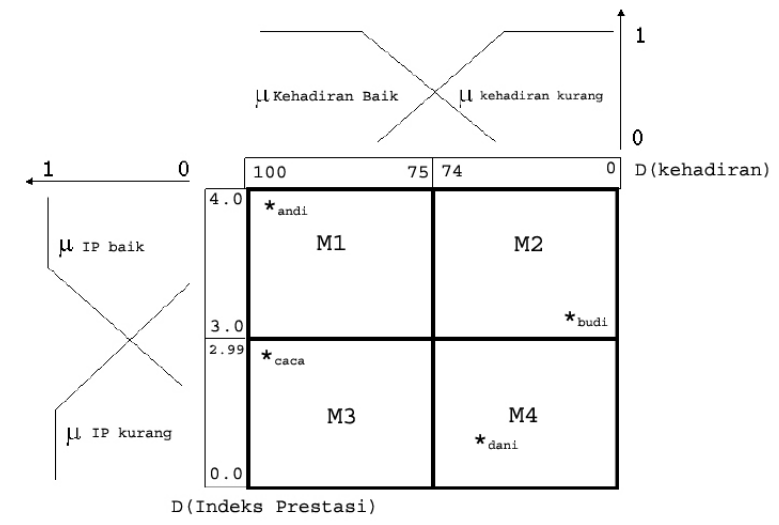

Gambar 3.1 Fuzzy classification untuk evaluasi kelayakan beasiswa

Fungsi keanggotaan Indeks prestasi :

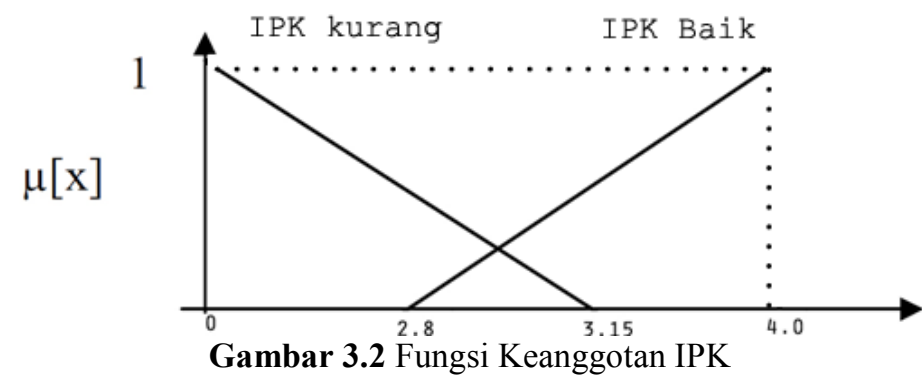

$\mu$ IPK kurang $[\mathrm{x}]=$

$$
\left\{\begin{aligned}
\frac{3,15-x^{1}}{3,15} & , x \leq 0 \\
0 & , \quad x \geq 3,15
\end{aligned}\right.
$$

$\mu$ IPK baik $[\mathrm{x}]$

$$
\left\{\begin{array}{cc}
\frac{x-2,8}{1,2} & , \quad x \leq 2,8 \\
1 & , \quad 2,8 \leq x \leq 4,0 \\
& , x \geq 4.0
\end{array}\right.
$$

Fungsi Keanggotaan frekuensi kehadiran: 


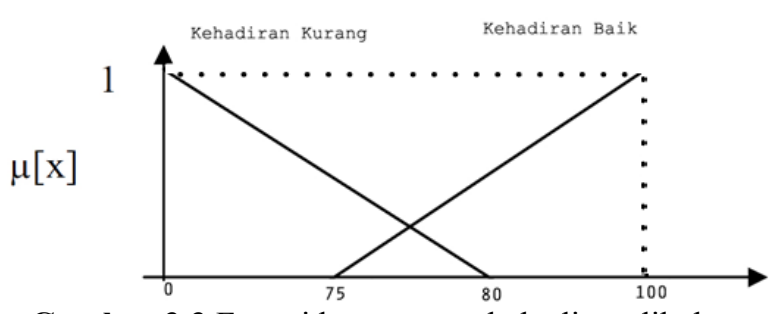

Gambar 3.3 Fungsi keanggotan kehadiran dikelas

$\mu$ kehadiran kurang $[\mathrm{x}]=$

$$
\left\{\begin{aligned}
1 & , x \leq 0 \\
\frac{80-x}{80} & , 0 \leq x \leq 80 \\
0 & , x \geq 80
\end{aligned}\right.
$$

$\mu$ kehadiran baik $[\mathrm{x}]=$

$$
\left\{\begin{array}{lll} 
& 0 & , x \leq 75 \\
\frac{x-75}{25} & & , 75 \leq x \leq 100 \\
& 1 & , x \geq 100
\end{array}\right.
$$

Berdasarkan fungsi keanggotaan di atas, maka posisi mahasiswa dalam kelas fuzzy classification dapat dihitung sebagai berikut:

a. Andi untuk nilai IPK 3,8 dan frekuensi kehadiran 90 persen.

$\mu$ IPK Baik $=(3,8-2,8) / 1,2=\mathbf{0 , 8 3}$.

$\mu$ IPK Kurang $=\mathbf{0}$

$\mu$ Kehadiran Baik $=(90-75) / 25=\mathbf{0 , 6}$

$\mu$ Kehadiran kurang $=\mathbf{0}$

b. Budi untuk nilai IPK sebesar 3,10 dan frekuensi kehadiran 70 persen.

$\mu$ IPK Baik $=(3,10-2,8) / 1,2=\mathbf{0 , 2 5}$

$\mu$ IPK Kurang $=(3,15-3,10) / 3,15=\mathbf{0 , 0 1 6}$

$\mu$ Kehadiran Baik $=\mathbf{0}$

$\mu$ Kehadrian kurang $=(80-70) / 80=\mathbf{0 , 1 2 5}$

c. Caca untuk nilai IPK sebesar 2,95 dan frekuensi kehadiran 90 persen.

$\mu$ IPK Baik $=(2,95-2,8) / 1,2=\mathbf{0 , 1 2 5}$

$\mu$ IPK Kurang $=(3,15-2,95) / 3,15=\mathbf{0 , 0 6 3}$

$\mu$ Kehadiran Baik $=(90-75) / 25=\mathbf{0 , 6}$

$\mu$ Kehadiran kurang $(x \geq 80)=\mathbf{0}$

d. Dani untuk nilai IPK sebesar 2,40 dan frekuensi kehadiran 60 persen.

$\mu$ IPK Baik $=\mathbf{0}$

$\mu \mathrm{IPK}$ Kurang $=(3,15-2,40) / 3,15=\mathbf{0 , 2 4}$

$\mu$ Kehadiran Baik $=\mathbf{0}$

$\mu$ Kehadiran kurang $=(80-60) / 80=\mathbf{0 . 2 5}$.

Selanjutnya nilai untuk keempat mahasiswa terhadap empat kelas fuzzy classification adalah sebagai berikut:

a. Kelas M1 untuk atribut ' $\mu$ IPK baik [x]' dan ' $\mu$ Kehadiran baik [x]':

$$
\begin{array}{ll}
\text { Andi } & : 0,83 * 0.6=\mathbf{0 . 4 9 8} \\
\text { Budi } & : 0,25 * 0=\mathbf{0 .} \\
\text { Caca } & : 0,125 * 0,6=\mathbf{0 , 0 7 5} . \\
\text { Dani } & : 0 * 0=\mathbf{0} .
\end{array}
$$

b. Kelas M2 untuk atribut $\mu$ IPK baik [x] dan $\mu$ Kehadiran kurang [x] :

$$
\begin{array}{ll}
\text { Andi } & : 0,83 * 0=\mathbf{0} . \\
\text { Budi } & : 0,25 * 0,125=\mathbf{0 . 0 1 3 2 5} \\
\text { Caca } & : 0,125 * 0=\mathbf{0} . \\
\text { Dani } & : 0 * 0.25=\mathbf{0} .
\end{array}
$$


c. Kelas M3 untuk atribut $\mu$ IPK kurang $[\mathrm{x}]$ dan $\mu$ Kehadiran Baik $[\mathrm{x}]$ :

$$
\begin{array}{ll}
\text { Andi } & : 0 * 0,6=\mathbf{0} . \\
\text { Budi } & : 0,016 * 0=\mathbf{0 .} \\
\text { Caca } & : 0,063 * 0,6=\mathbf{0 , 0 3 7 8 .} \\
\text { Dani } & : 0,24 * 0=\mathbf{0}
\end{array}
$$

d. Kelas M4 untuk atribut $\mu$ IPK kurang [x] dan $\mu$ Kehadiran kurang [x] :

$$
\begin{array}{ll}
\text { Andi } & : 0 * 0=\mathbf{0} . \\
\text { Budi } & : 0,016 * 0,125=\mathbf{0 . 0 0 2} \\
\text { Caca } & : 0,063 * 0=\mathbf{0} . \\
\text { Dani } & : 0,24 * 0.25=\mathbf{0 . 0 0 6}
\end{array}
$$

Berdasarkan hasil perhitungan di atas, yang berada di kelas M1 adalah Andi dan Caca; untuk kelas M2 adalah Budi; kelas M3 adalah Caca; dan kelas M4 adalah Budi dan Dani. Dari perhitungan di atas maka beasiswa 'caca' tetap dipertahankan karena caca juga termasuk di dalam bagian kelas M1 yang merupakan kelas aman. Sedangkan beasiswa 'budi' tidak diperpanjang karena selain masuk di kelas M2, 'budi' juga menjadi bagian dari kelas M4 yang merupakan kelas tidak aman.

\subsubsection{Pengimplementasian Relasi}

SRM bertanggung jawab untuk memelihara hubungan antara institusi dengan mahasiswa agar tetap efektif. Pada penelitian ini, tindakan disampaikan melalui dosen wali untuk selanjutkan disampaikan kepada pihak yang bersangkutan. Nantinya proses penyampaian dan tanggapan mahasiswa terhadap action yang diberikan oleh dosen wali akan dicatat oleh dosen wali tersebut dan disimpan di dalam sistem sebagai bahan evaluasi.

\subsection{Persistent Data}

Dalam sistem ini terdapat dua buah repositori data dengan tujuan penyimpanan yang berbeda. Yang pertama berupa basis data operasional yang bertujuan menyimpan keseluruhan data yang dibutuhkan oleh sistem yaitu data akademik dan aktivitas akademik yang dipergunakan bagi kegiatan operasional akademik. Sedangkan repositori data yang kedua berupa data marts yang dipergunakan untuk menyimpan data fakta fakta dari aktivitas akademik mahasiswa yang nantinya akan dianalisis oleh sistem untuk memperoleh pengetahuan yang dibutuhkan pengguna. Gambar 3.4 menunjukkan tabel tabel penyusun data marts yang dipergunakan.

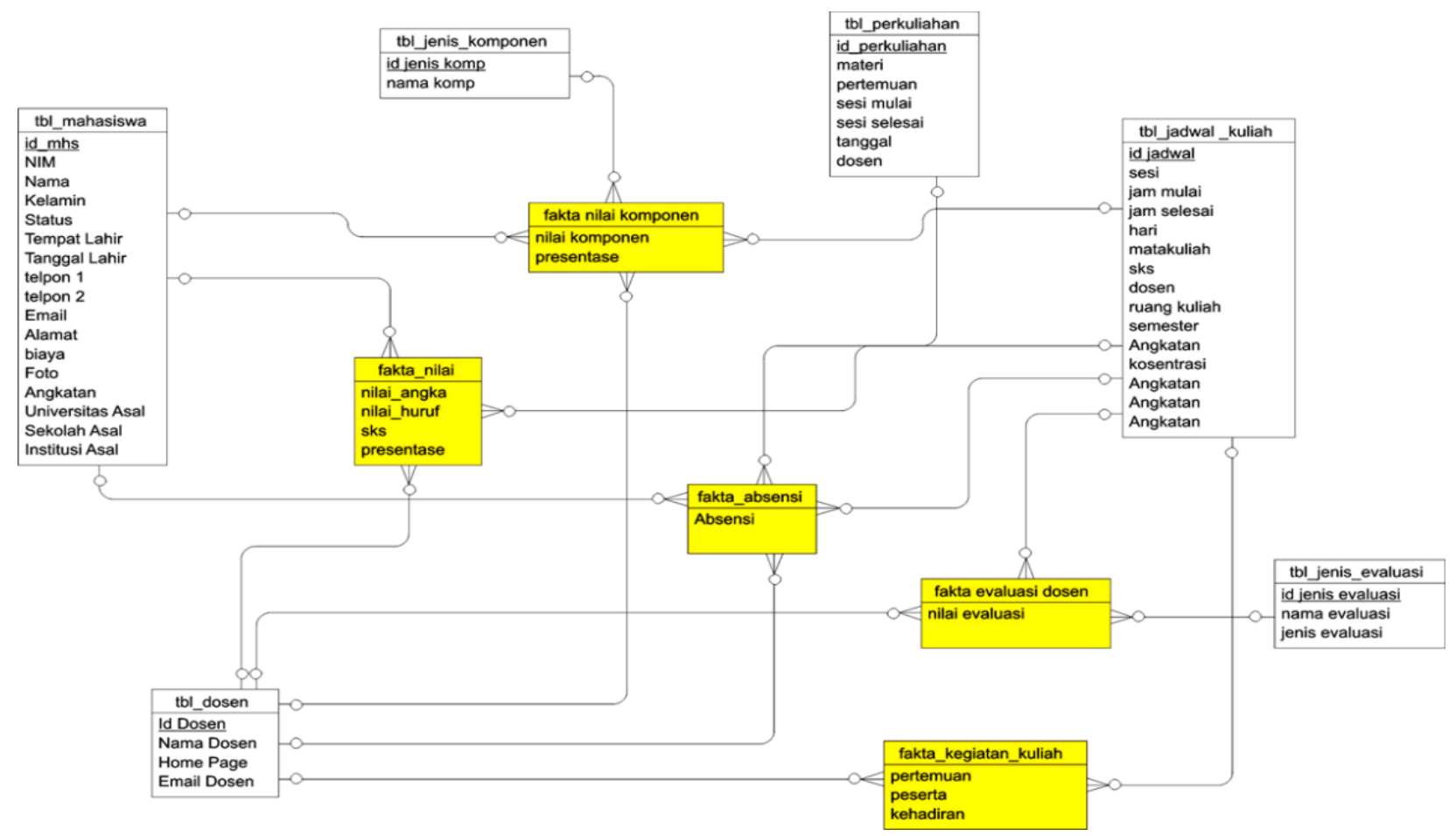

Gambar 3.4 Data Marts: fakta 


\section{Hasil Penelitian dan Pembahasan}

\subsubsection{Implementasi Sistem} berikut:

Form form yang terdapat pada perangkat lunak SRM dapat dibagi kedalam empat bagian utama sebagai

- Pengelolaan account pengguna yang berfungsi untuk mengelola account dari pengguna perangkat lunak ini beserta dengan hak aksesnya.

- Pengelolaan data akademik dan data aktivitas akademik. Pada bagian ini terdapat dua metode dalam mengolah data yaitu pengelolaan secara manual menggunakan form yang telah disediakan dan pengelolaan yang terintegrasi langsung dengan basis data berbasis mysql dari Sistem Informasi Akademik MTI UGM Yogyakarta dengan menggunakan fasilitas linked server dari SQL server 2008.

- Pengelolaan pemerolehan pengetahuan (knowledge) yang berfungsi untuk mengelola proses pemerolehan pengetahuan terhadap suatu objek berdasarkan atribut yang terkait dengan objek tersebut menggunakan metode fuzzy classification untuk selanjutnya disampaikan kepada pihak pihak yang terkait sehingga bentuk relasi dapat terjalin.

\subsubsection{Pembahasan}

Arsitektur dari Student Relationship Management disusun oleh empat buah komponen yaitu data acquisition and storage, data analysis, interaction, dan assessment.

\section{Data acquisition}

Komponen data acquisition diwujudkan dengan membangun dua buah metode pemerolehan data dan metode ETL yang terintegrasi dengan sistem yaitu metode manual menggunakan form yang telah tersedia, dan metode yang terintegrasi dengan basis data dari sistem informasi akademik MTI UGM Yogyakarta. Dengan adanya sistem yang terintegrasi, memudahkan pengguna dalam memperoleh data yang dibutuhkan tanpa harus bekerja dua kali untuk memasukkan data. Sebaliknya dengan adanya fasilitas untuk mengolahnya secara manual membuat sistem SRM tidak terlalu bergantung dengan Sistem Informasi Akademik (SIA) perguruan tinggi.

Dalam penelitian kali ini proses data acquisition diwujudkan dengan mengintegrasikan basis data dari SRM dengan basis data dari SIA MTI UGM Yogyakarta. Basis data dari SIA MTI UGM Yogyakarta dibangun menggunakan Mysql. Sedangkan database dan data marts dari SRM dibangun menggunakan aplikasi Microsoft Sql Server 2008. Untuk mengintegrasikan kedua basis data tersebut, perlu dibangun sebuah linked server yang akan menghubungkan kedua basis data tersebut.

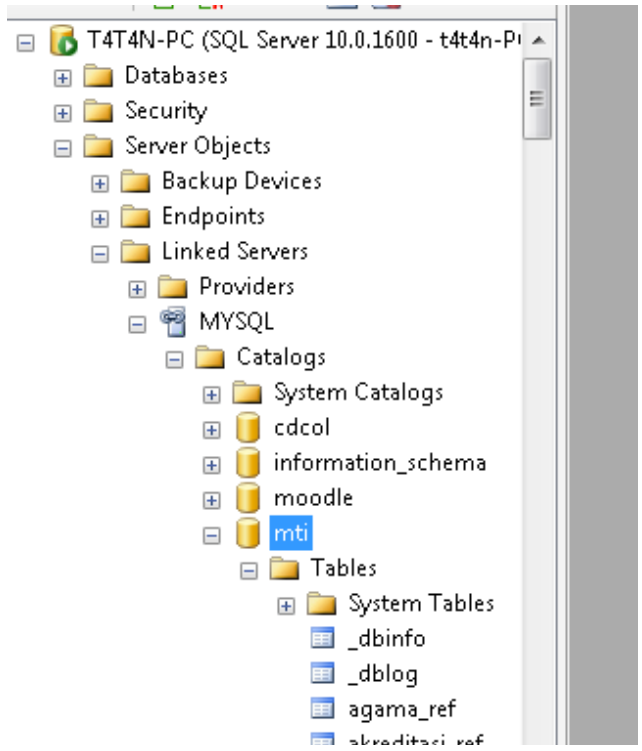

Gambar 4.1 Linked server yang terbentuk di Sql Server Management Studio

\section{Data Analysis}

Komponen data analysis di implementasikan dengan menggunakan metode data mining, yaitu fuzzy classification. Kelebihan fuzzy classification dibandingkan dengan metode klasifikasi biasa adalah kemampuan untuk mengelompokkan atau mengklasifikasikan suatu objek pada lebih dari satu kelas klasifikasi pada waktu yang bersamaan. Dengan kelebihan tersebut, proses pengambilan suatu tindakan terhadap suatu objek bisa diambil berdasarkan lebih dari satu kelas klasifikasi yang terbentuk. 
Dengan kelebihan tersebut, proses pengambilan suatu tindakan terhadap suatu objek bisa diambil berdasarkan lebih dari satu kondisi klasifikasi. Selanjutnya akan dijabarkan contoh dari penggunaan fuzzy classification menggunakan sample data dari mahasiswa MTI UGM kelas CIO pada semester tertentu. Atribut yang digunakan untuk menganalisis objek mahasiswa adalah atribut presensi, ujian, tugas, dan presentasi atau keaktifan dari mahasiswa CIO MTI UGM Yogyakarta. Perhitungan menggunakan keempat atribut tersebut menghasilkan lima belas kelas klasifikasi seperti ditunjukkan pada Gambar 4.2.

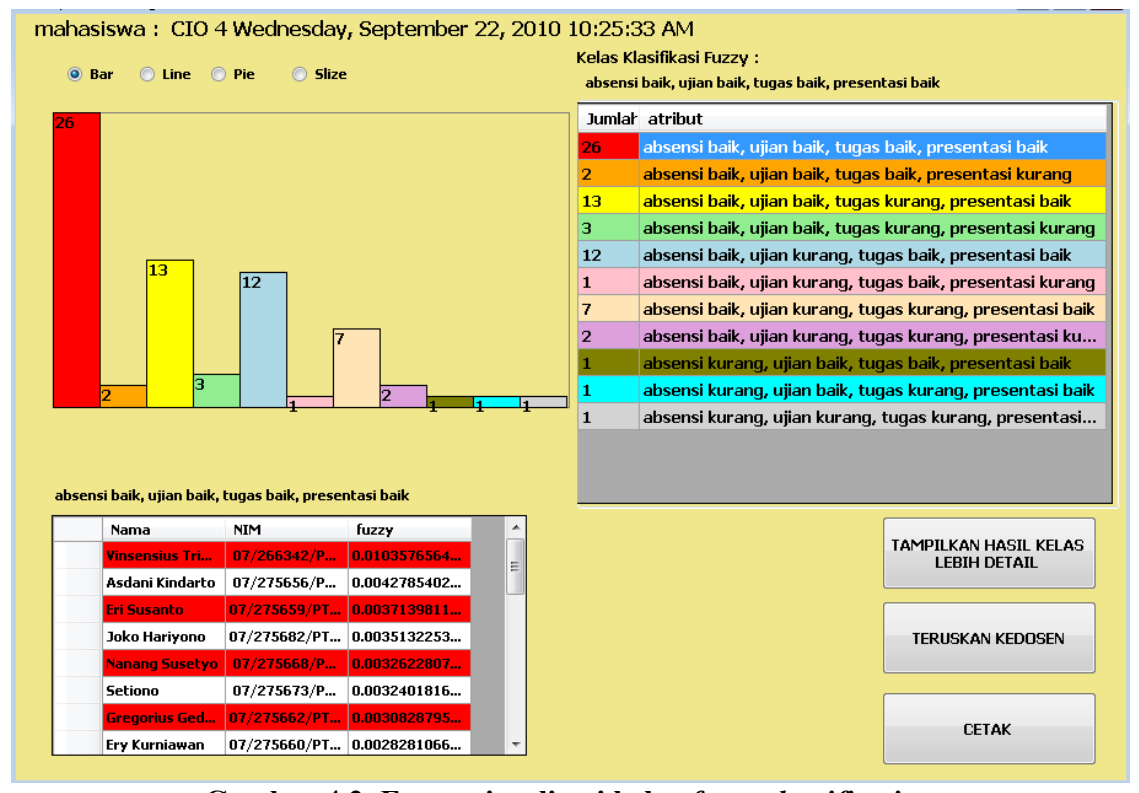

Gambar 4.2 Form viusalisasi kelas fuzzy classification

Gambar 4.2 menunjukkan bagaimana kelas fuzzy classification terbentuk berdasarkan keempat atribut perkuliahan yang dipergunakan. Pola yang terbentuk ditampilkan baik secara grafis visual dan statistik. Pola pola yang terbentuk dari proses klasifikasi tersebut akan menjadi sebuah knowledge yang selanjutnya akan dijadikan acuan untuk melakukan tindakan sesuai dengan hasil atribut dari data mahasiswa. Selanjutnya dari sebelas kelas yang terbentuk tersebut dapat di drilldown untuk melihat detil dari masing masing kelas seperti ditunjukkan pada gambar 4.3 dan 4.4.

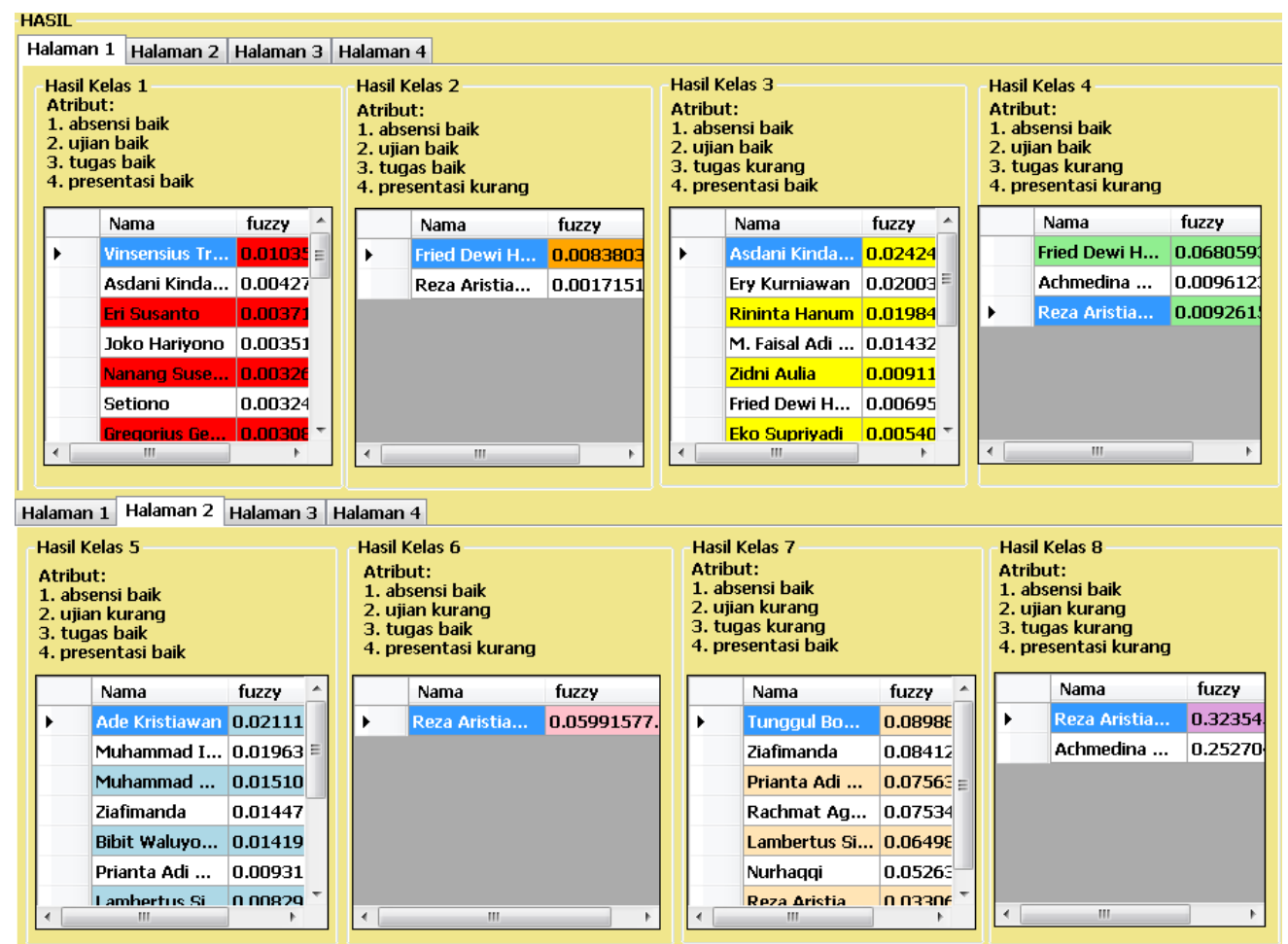

Gambar 4.3 Form drilldown kelas klasifikasi pertama 


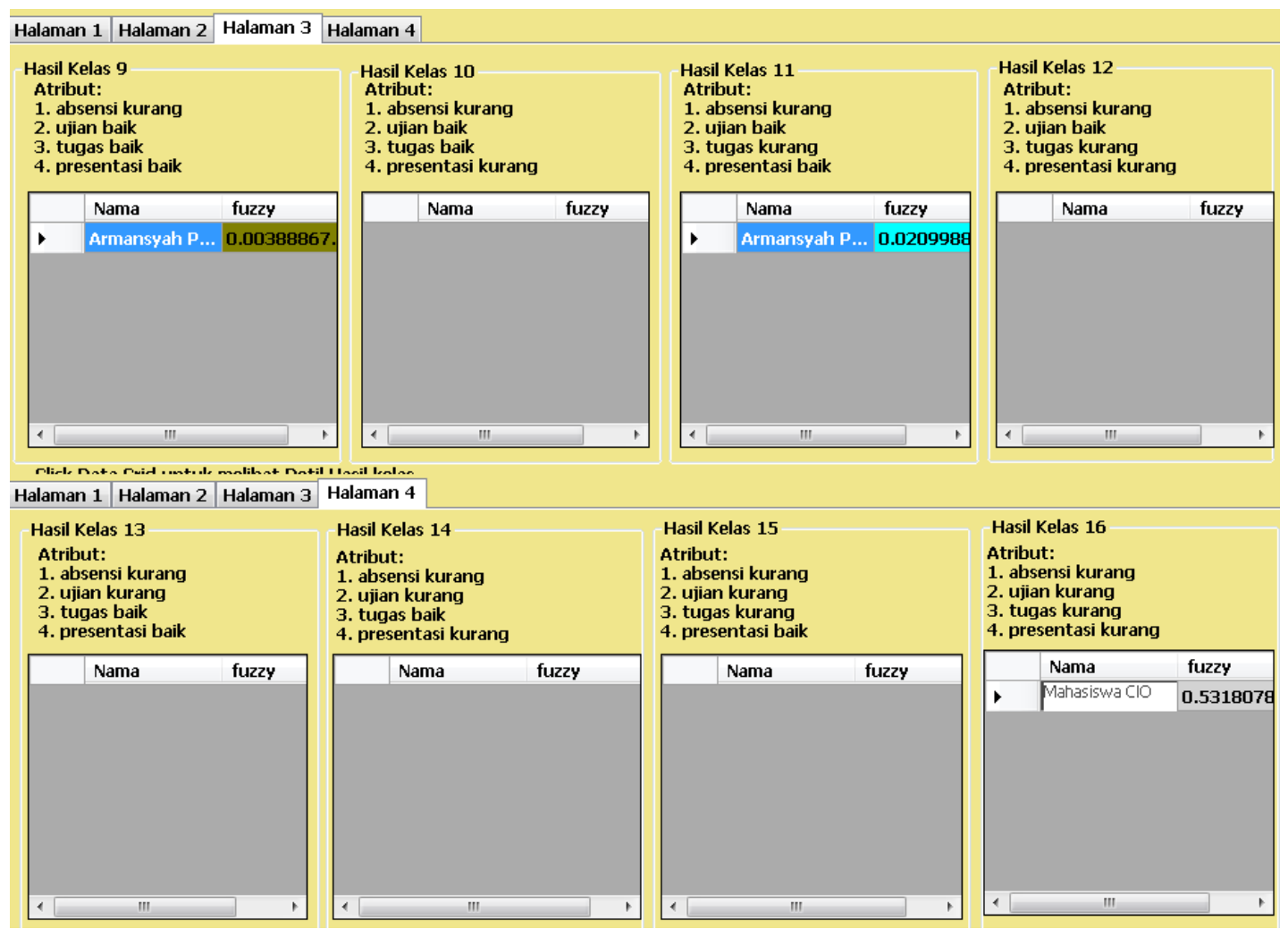

Gambar 4.4 Form drilldown kelas klasifikasi kedua

Dari sebelas kelas yang terbentuk tersebut dapat dijadikan dasar untuk mengambil sebuah action berdasarkan knowledge yang ditampilkan. Sebagai contoh terdapat hasil yang cukup menarik dari kelas yang terbentuk. Terdapat seorang mahasiswa yang selalu muncul pada kelas yang memiliki atribut "presentasi atau keaktifan' baik. Hal tersebut menunjukkan bahwa mahasiswa tersebut memiliki kelebihan pada aktivitas akademik 'presentasi atau keaktifan dan kurang untuk aktivitas lainnya. Hal tersebut dapat digunakan sebagai dasar untuk melakukan tindakan yang tepat berdasarkan hasil dari aktivitas akademik mahasiswa yang bersangkutan. Tidak berhenti sampai disini, sistem juga mampu menampilkan data history pengetahuan yang diperoleh dari masing masing siswa pada periode tertentu baik secara individu ataupun kolektif. Dengan begitu pola aktivitas akademik mahasiswa dapat dianalis dari waktu ke waktu seperti ditunjukkan pada gambar 4.5.

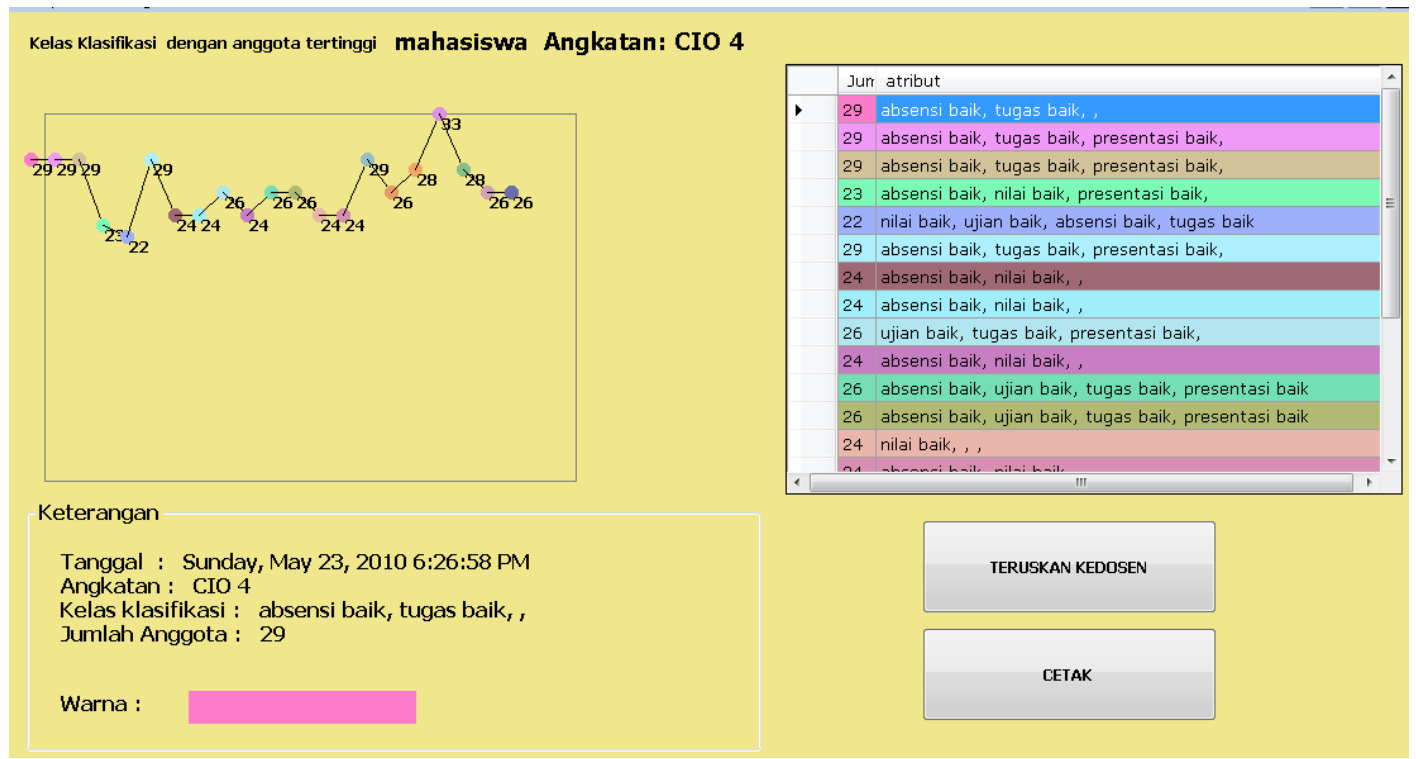

Gambar 4.5 Form visualisasi history knowledge 


\section{Interaction and Assessment}

Perwujudan komponen interaction dan assessment terletak pada adanya fasilitas email client (smtp dan pop3) yang ditanamkan pada aplikasi SRM tersebut. Melalui fasilitas tersebut, pengetahuan dan tindakan yang didapatkan dapat disampaikan kepada pihak yang berkepentingan seperti dosen wali, dosen pengawas ataupun pengelola melalui fasilitas email untuk disampaikan kepada objek yang bersangkutan baik itu mahasiswa, dosen, atau pihak yang terkait dengan proses perkuliahan tertentu. Selanjutnya respon dari action yang telah disampaikan oleh pihak terkait akan dilaporkan melalui email yang dapat diunduh dan disimpan di basis data aplikasi SRM, untuk selanjutnya dapat dijadikan sebagai bahan analisa untuk melakukan tindakan di masa yang akan datang.

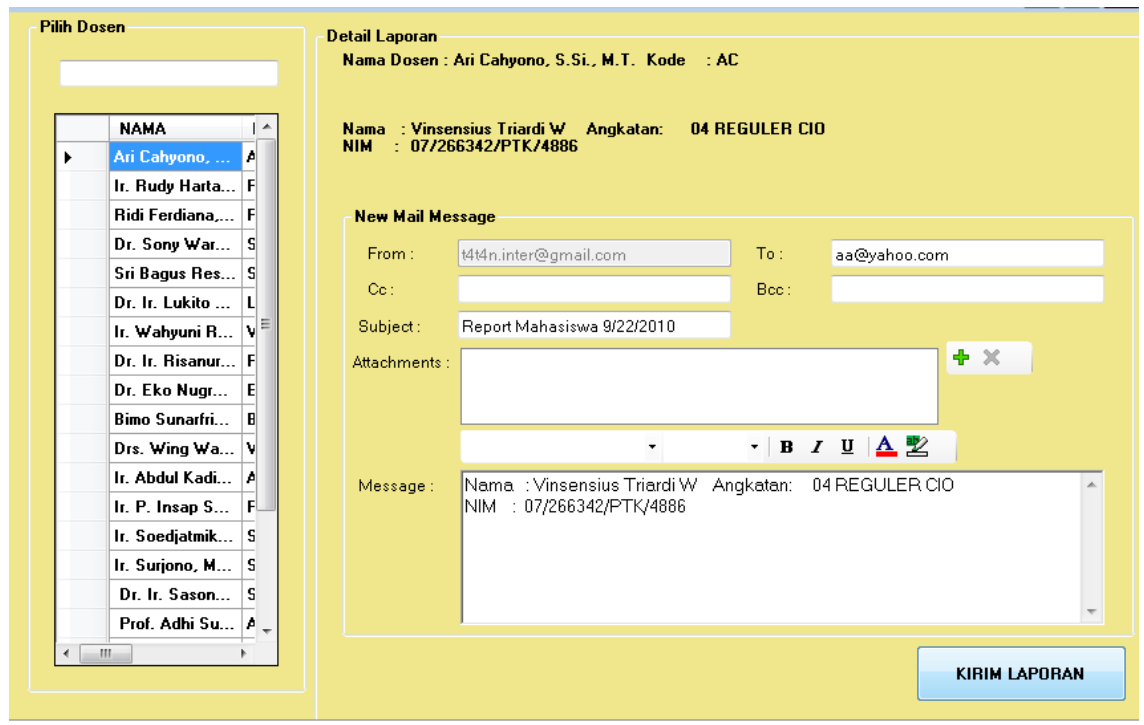

Gambar 4.6 Form penyampaian knowledge kepada dosen wali

\section{Kesimpulan} berikut:

Dari uraian yang telah dipaparkan pada bab bab sebelumnya, maka dapat diambil kesimpulan sebagai

1. Aplikasi SRM mampu untuk memberikan pengetahuan yang didapatkan melalui proses klasifikasi terhadap data aktivitas akademik menggunakan metode fuzzy classification. Dari kelas yang terbentuk akan didapatkan sebuah pola atau prilaku dari aktivitas akademik mahasiswa pada angkatan tertentu, dan dapat diketahui atribut kegiatan akademik mana sajakah yang mengalami penurunan atau peningkatan performa. Berbekal dari pengetahuan tersebut, pihak pengelola dapat memutuskan tindakan yang sesuai untuk meningkatkan performa akademik mahasiswa baik secara umum (untuk keseluruhan angkatan) atau secara khusus (untuk mahasiswa tertentu) pada wilayah sasaran yang lebih terarah.

2. Proses relasi diwujudkan melalui tindakan yang dilakukan pihak institusi pendidikan berdasarkan pengetahuan yang didapatkan. Setelah tindakan tersebut dieksekusi maka respon dihasilkan akan dicatat dan menjadi bekal untuk mengevaluasi kembali performa aktivitas akademik pada periode selanjutnya. Proses di atas memungkinkan pihak perguruan tinggi untuk mempererat relasi antara mahasiswa dengan institusi dalam hal pengawasan dan tindakan secara tepat dan terarah terhadap performa aktivitas akademik mahasiswa di sebuah perguruan tinggi. 


\section{Daftar Pustaka.}

Chen, Hang. 2006. “Applications of Fuzzy Logic in Data Mining Process”, Advanced Fuzzy Logic Technologies in Industrial Applications, hal. 249-260. London: Springer.

Machado, Melissa; Oliveira, Jonice; \& de Souza, Jano M. 2007. "Customer Relationship Management in Universities and Research Centres". This paper appears in Computer Supported Cooperative Work in Design, 2007. CSCWD 2007. 11th International Conference on.

Meier, Andreas; Werro, Nicolas; Albrecht, Martin; \& Sarakinos, Miltiadis. 2005. "Using a Fuzzy Classification Query Language for Customer Relationship Management". Proceedings of the 31 st International Conference on Very Large Data Bases, VLDB 2005, Trondheim, Norway, August 2005.

Nakajima, H; Sogoh, T; \& Arao, M. 1993. "Fuzzy Database Language and Library :

Fuzzy Extension to SQL”. Proceedings of 2nd IEEE International Conference on Fuzzy Systems,, pp. 477-482.

Nakajima, H. 1996. "Fuzzy Logic and Data Mining, Soft. Computing in Intelligent Systems and Information Processing”. Proceedings of the 1996 Asian Fuzzy Systems, 1996.

Negash, Solomon \& Gray,Paul. 2003. "Business Intelligence". Ninth Americas Conference on Information Systems.

Piedade, Maria Beatriz; \& Santos, Maribel Yasmina. 2008. "Student Relationship Management: Concept, Practice and Technological Support". This paper appears in Engineering Management Conference, 2008. IEMC Europe 2008. IEEE International.

Ponniah, Paulraj. 2001. "Data Warehousing Fundamentals : A Comprehensive Guide for IT Professionals". John Wiley \& Sons, Inc.

Rainardi, Vincent. 2008. "Building a Data Warehouse With Examples in SQL Server”. New York: Apress.

Seeman, Elaine D. \& O'Hara, Margaret. 2006. "Customer Relationship Management in Higher Education". Campus-Wide Information Systems, vol. 23, pp. 24-34.

Strong, Diane M; Lee, Yang W; Wang, Richard Y.2007. "Data Quality in Context”. Communications of the ACM.

Turban,Efraim; Aronson, Jay E.; \& Liang, Ting Pen. 2005. Decision Support Systems and Intelligent Systems. Dwi Prabantini (Penterjemah). Yogyakarta: Penerbit Andi. 